University of Nebraska - Lincoln

DigitalCommons@University of Nebraska - Lincoln

Preface to "When Does Sample Matter in Juror Decision-Making Research? Differences Between College Student and Representative Samples of Jurors"

Joel D. Lieberman

University of Nevada, Las Vegas, NV, jdl@unlv.nevada.edu

Daniel A. Krauss

Claremont McKenna College, Claremont, CA, dkrauss@cmc.edu

Richard L. Weiner

University of Nebraska-Lincoln, rwiener2@unl.edu

Follow this and additional works at: https://digitalcommons.unl.edu/psychfacpub

Part of the Law Commons, and the Psychology Commons

Lieberman, Joel D.; Krauss, Daniel A.; and Weiner, Richard L., "Preface to "When Does Sample Matter in Juror Decision-Making Research? Differences Between College Student and Representative Samples of Jurors"'" (2011). Faculty Publications, Department of Psychology. 943.

https://digitalcommons.unl.edu/psychfacpub/943

This Article is brought to you for free and open access by the Psychology, Department of at DigitalCommons@University of Nebraska - Lincoln. It has been accepted for inclusion in Faculty Publications, Department of Psychology by an authorized administrator of DigitalCommons@University of Nebraska - Lincoln. 


\title{
Preface to "When Does Sample Matter in Juror Decision-Making Research? Differences Between College Student and Representative Samples of Jurors"
}

\author{
Joel D. Lieberman, ${ }^{1}$ Daniel A. Krauss, ${ }^{2}$ and \\ Richard L. Wiener ${ }^{3}$ \\ 1 University of Nevada, Las Vegas, NV \\ 2 Claremont McKenna College, Claremont, CA \\ 3 University of Nebraska-Lincoln \\ Corresponding author - Richard L. Wiener, University of Nebraska at Lincoln, \\ Department of Psychology, 238 Burnett Hall, P.O. Box 880308, Lincoln, NE 68588-0308, U.S.A. \\ Email: rwiener2@unl.edu
}

\section{Introduction}

It has been 45 years since Kalven and Zeisel (1966) published their groundbreaking book The American Jury. Since that time, the field of jury decision-making has grown dramatically. A multitude of social and cognitive influences on juror behavior have been identified, as has the influence of many procedural factors such as jury size, jury decision rule, and jury instructions. Several broad theories have been developed that integrate findings, such as commonsense justice (Finkel, 1995, 2001) and the story model (Pennington \& Hastie, 1992). Interestingly, although The American Jury may have marked the beginning

Published in Behavioral Sciences and the Law 29 (2011), pp 325-327.

DOI: $10.1002 /$ bsl.987

Copyright (C) 2011 John Wiley \& Sons, Ltd. Used by permission. 
of the era of jury decision-making research, it did not set the tone for how research in the area is typically conducted. Whereas Kalvin and Zeisel studied the behavior of jurors in actual trials, the vast majority of studies that followed have involved trial simulations, with college students used as participants. This sampling approach has become widespread despite frequent criticism from the legal community for using students as mock jurors. In this special issue, we examine the impact of using college students compared with more representative samples of jurors.

Although there are clearly excellent examples of jury researchers using more representative samples of participants, the trend noted in several meta-analyses in jury decision-making research is that the use of college student mock jury samples continues to rise (Bornstein, 1999; Devine, Clayton, Dunford, Seying, \& Pryce, 2001). This trend is not surprising given that the extant psycholegal research has generally found few consistent differences between college student and representative samples (Bornstein, 1999; but see Diamond, 1997 for a number of notable exceptions to this rule), the convenience of using college student samples, and the expense and difficulty of obtaining more representative participant pools. Indeed, it has almost become de rigueur for researchers to briefly acknowledge that the use of a college student sample might be a research limitation. However, as Bornstein (1999) pointed out, it is "striking" how few studies have directly compared college students with more representative samples. Consequently, we were interested in gathering studies that could shed additional light on the issue of sampling effects (or lack thereof ).

In compiling this special issue, we were especially interested in determining if a more nuanced conclusion to the issue of sample representativeness in jury simulation research might be appropriate. To put it even more succinctly, we thought the answer to the question of whether sample matters in jury decision-making research is not that it generally doesn't matter, but that "it depends". The goal of this special issue is to identify additional contexts where sample may be a relevant factor. The manipulated and outcome variables employed, legal standards used, the psychological processes being studied and manipulated, and the legal setting in which the research is being completed, as well as many other factors, may affect results and produce interesting interactions with sample. 
This special issue begins with a commentary by Judge William Caprathe providing a judicial perspective regarding the importance of sample representativeness and the general ecological validity of psycholegal studies in the area of jury decision-making. We believed that this viewpoint was particularly important given that the bench has historically criticized this work, and that legal actors have not interpreted this work appropriately or made use of it for addressing important legal questions. The issue then contains seven articles that explore the importance of differences and similarities between college student and more representative mock jury samples in a wide diversity of legal contexts, including: (1) The effect of acknowledging mock jurors' feelings on affective and cognitive biases: it depends on the sample (McCabe \& Krauss, 2011); (2) the effects of different compensation rules in medical malpractice decisions [A Comparison of Students' and Jury Panelists' Decision-Making in Split Recovery Cases (Fox, Wingrove, \& Pfeifer, 2011)]; (3) guilt or innocence decisions across sexual assault and homicide cases [What are we studying? Student Jurors, Community Jurors, and Construct Validity (Keller \& Wiener, 2011)]; (4) verdicts in medical malpractice decision involving different types of injuries [How Reason for Surgery and Patient Weight Affect Verdicts and Perceptions in Medical Malpractice Trials: A Comparison of Students and Jurors (Reichert, Miller, Bornstein, \& Shelton, 2011)]; (5) verdicts in sexual harassment cases involving a Latina plaintiff [Sexual Harassment Trials Involving Latina Plaintiffs: Effects of a Cultural Relativist Argument and Juror Background (Schwartz \& Hunt, 2011)]; (6) whether these sample differences should be more pronounced when deliberations are included in decision-making [Jury Decision-Making Research: Are Researchers Focusing on the Mouse and Not the Elephant in the Room? (Nuñez, McCrea, \& Culhane, 2011)]; and (7) verdict and sentencing recommendations in a simulated burglary case [Town vs. Gown: A Direct Comparison of Community Residents and Student Mock Jurors (Hosch, Culhane, Tubb, \& Granillo, 2011)]. The issue concludes with an article written by the editors - Mock Jury Research: Where Do We Go from Here? (Wiener, Krauss, \& Lieberman, 2011) - in which we tried to integrate consistencies and inconsistencies from the studies in this volume, and offer a framework that we believe offers a useful way of thinking about future research on sample differences in mock jury decision-making research. 
Our ultimate goal of this volume is to inspire researchers to consider more carefully the potential effects of sample characteristics and the conditions where sample differences are likely to emerge. Hopefully, such a consideration will help advance the field and lead to greater acceptance of research on jury decision-making within the legal community.

\section{References}

Bornstein, B. H. (1999). The ecological validity of jury simulations: Is the jury still out? Law and Human Behavior, 23, 75-91.

Devine, D. J., Clayton, L. D., Dunford, B. B. Seying, R. S., \& Pryce, J. (2001). Jury decision making: 45 years of empirical research on deliberating groups. Psychology, Public Policy, \& Law, 7, 622-727.

Diamond, S. S. (1997). Illuminations and shadows from jury simulations. Law and Human Behavior, 21, 561-571.

Finkel, N. J. (1995). Commonsense justice: Jurors' notions of the law. Cambridge, MA: Harvard University Press.

Finkel, N. J. (2001). Not fair! The typology of commonsense fairness. Washington D.C.: American Psychological Association.

Fox, P., Wingrove, T., \& Pfeifer, C. (2011). A comparison of students' and jury panelists' decision-making in split recovery cases. Behavioral Sciences and the Law, 29, 358-375. DOI: 10.1002/bsl.968.

Hosch, H. M., Culhane, S. E., Tubb, V. A., \& Granillo, E. A. (2011). Town vs. gown: A direct comparison of community residents and student mock jurors. Behavioral Sciences and the Law, 29, 452-466. DOI: 10.1002/bsl.970.

Kalven, H., \& Zeisel, H. (1966). The American jury. Boston: Little, Brown.

Keller, S. R., \& Wiener, R. L. (2011). What are we studying? Student jurors, community jurors, and construct validity. Behavioral Sciences and the Law, 29, 376-394. DOI: 10.1002/bsl.971.

McCabe, J. G., \& Krauss, D. A. (2011). The effect of acknowledging mock jurors' feelings on affective and cognitive biases: It depends on the sample. Behavioral Sciences and the Law, 29, 331-357. DOI: 10.1002/ bsl.990.

Nuñez, N., McCrea, S. M., \& Culhane, S. E. (2011). Jury decision making research: Are researchers focusing on the mouse and not the elephant in the room? Behavioral Sciences and the Law, 29, 439-451. DOI: 10.1002/bsl.967.

Pennington, N., \& Hastie, R. (1992). Explaining the evidence: Tests of the story model for juror decision making. Journal of Personality and Social Psychology, 62, 189-206. 
Reichert, J., Miller, M. M., Bornstein, B. H., \& Shelton, D. E. (2011). How reason for surgery and patient weight affect verdicts and perceptions in medical malpractice trials: A comparison of students and jurors. Behavioral Sciences and the Law, 29, 395-418. DOI: 10.1002/bsl.969.

Schwartz, S. L., \& Hunt, J. S. (2011). Sexual harassment trials involving Latina plaintiffs: Effects of a cultural relativist argument and juror background. Behavioral Sciences and the Law, 29, 419-438. DOI: 10.1002/ bsl.972.

Wiener, R. L., Krauss, D. A., \& Lieberman, J. D. (2011). Mock jury research: Where to we go from here? Behavioral Sciences and the Law, 29, 467-479. DOI: 10.1002/bsl.989. 